\title{
REGENERATION OF BITTER GOURD (Momordica charantia L.) FROM LEAF SEGMENTS AND ROOT TIPS
}

\author{
M. A. Z. Al Munsur, M. S. Haque, K. M. Nasiruddin and M. J. Hasan \\ Department of Biotechnology, Bangladesh Agricultural University \\ Mymensingh-2202, Bangladesh
}

\begin{abstract}
Experiments were carried out to study the callus induction and subsequent plantlet regeneration ability of leaf segments and root tips of bitter gourd. A combination of $1.0 \mathrm{mg} \mathrm{L}^{-1} 2,4-\mathrm{D}$ and $1.0 \mathrm{mg} \mathrm{L}^{-1} \mathrm{BAP}$ produced the highest percentage of callus in leaf segments $(78.75 \%)$ and $1.0 \mathrm{mg} \mathrm{L}^{-1} 2,4-\mathrm{D}$ combined with $0.5 \mathrm{mg} \mathrm{L}^{-1} \mathrm{BAP}$ produced the highest callus frequency in root tips $(72.5 \%)$. Using the combination of BAP at $2.0 \mathrm{mg} \mathrm{L}^{-1}$ and NAA at $0.3 \mathrm{mg} \mathrm{L}^{-1}$ improved the callus induction frequency $(80.00 \%)$ in root tips. Root tips showed better response than leaf segments in callus induction. Leaf segments and root tips had equal percentage (65.0) of shoot regeneration upon culture of the calli on medium with 2.0 or $2.5 \mathrm{mg} \mathrm{L}^{-1} \mathrm{BAP}$ with $0.2 \mathrm{mg}$ $\mathrm{L}^{-1}$ IAA. The highest length $(3.95 \mathrm{~cm})$ of shoot from leaf segments was recorded with $2.5 \mathrm{mg} \mathrm{L}^{-1} \mathrm{BAP}, 0.5 \mathrm{mg} \mathrm{L}^{-1} \mathrm{IBA}$ and $0.2 \mathrm{mg} \mathrm{L}^{-1} \mathrm{GA}_{3}$. The highest number of roots $(6.75)$ and root length $(2.45 \mathrm{~cm})$ were found in 3.0 $\mathrm{mg} \mathrm{L}^{-1} \mathrm{BAP}$ with $0.1 \mathrm{mg} \mathrm{L}^{-1} \mathrm{NAA}$ in root tips. The callus formation and regeneration ability of the explants have the potential for use in future biochemical studies and genetic improvement of bitter gourd.
\end{abstract}

Key Words : Bitter gourd, In vitro regeneration, Leaf segments, Momordica charantia, Root tips

\section{INTRODUCTION}

Momordica is a genus of herbaceous annual or perennial climbers with 45 species native to tropical Asia and Africa. Momordica charantia is the most common among the six species cultivated for their fruits used as vegetables. It is believed to have originated in the tropics of the old world and is widely distributed in China, Malaysia, India, Tropical Africa and America (Kirtikar and Basu, 1994). Bitter gourd (Momordica charantia L.) belongs to the family Cucurbiteceae and is an economically important, expensive summer vegetable in Bangladesh. The fruits of bitter gourd contain nutritionally useful quantities of minerals and amino acids. The fruit contains very high amount of vitamins $\mathrm{A}$ and $\mathrm{C}$, iron and minerals. Slices of unripe fruits are served as different types of curries and fried forms. The bitter taste is liked by some people and supposed to contain medicinal properties (Choudhury, 1967). It has hypoglycemic activity which reduces the blood glucose in diabetic rats (Perl, 1988; Khan, 1999). It has possible anti tumor activity (Xue et al., 1998), antispermatogenic and androgenic activities (Naseem et al., 1998). The abortifacient protein includes momorcharin from M. charantia. Bitter gourd has bright red seeds due to high lycopene content which can be used as an artificial food colorant (Yen 
and Hwang, 1985). Bitter gourd protein (MRK29) has been reported to be used as HIV inhibitor (Jiratchariyakul et al., 2001).

Bitter gourd is tolerant to a range of environments (Lim, 1998) and can be grown in tropical and subtropical climates (Reyes et al., 1994). Improvement of this crop and development of a new variety with desirable traits are obviously necessary which could be done through the applications of modern techniques of biotechnology. Genetic transformation techniques have been used as efficient tools for the breeding of crops. A reproducible protocol for in vitro regeneration is a prerequisite for varietal improvement through genetic engineering. Many factors determine in vitro regeneration. A balance between auxin and cytokinin regulates the in vitro regeneration from explants culture on artificial medium. The growth condition and suitable explants are also needed to be standardized for efficient utilization of tissue culture for genetic improvement of bitter gourd. There have not been many studies for the development of in vitro protocol to be used the improvement of bitter gourd in Bangladesh or its neighboring countries. The present study was, therefore, carried out to select the most suitable explants for in vitro regeneration, and to develop an efficient protocol for in vitro plant regeneration of bitter gourd.

\section{MATERIALS AND METHODS}

Seeds of a hybrid variety of bitter gourd marketed by the East West Seed (Bangladesh) Ltd. were purchased from local market. For the improvement of germination, the collected seeds were treated with hot water at $55-57^{\circ} \mathrm{C}$ for $15 \mathrm{~min}$ by using the "Vegetable Seed Treating Device" developed by IPM Laboratory, Department of Plant Pathology, Bangladesh Agricultural University. Then the seeds were dried overnight under shade. The seeds were surface sterilized with $70 \%$ ethanol for 30 seconds and again then with $0.1 \%(\mathrm{w} / \mathrm{v})$ mercuric chloride solution for five minutes. The seeds were then rinsed for 3-4 times by sterile distilled water to remove traces of $\mathrm{HgCl}_{2}$. Then the seeds were placed on hormone free half strength MS (Murashige and Skoog, 1962) medium for germination. Seeds started germination within four days of inoculation and subsequently developed into rooted plantlets within 10 to12 days. Leaf segments and root tips were dissected out from the 12-days old plantlets and used as explants. The explants were then cultured on MS medium supplemented with various concentrations and combinations of 2,4-D (0.0, $0.25,0.50,1.0$ and $\left.5.0 \mathrm{mg} \mathrm{L}^{-1}\right)$, BAP $\left(0.2,0.5,1.0,2.0,2.5\right.$ and $\left.3.0 \mathrm{mg} \mathrm{L}^{-1}\right)$ and NAA $(0.1,0.3$ and $0.6 \mathrm{mg} \mathrm{L}^{-1}$ ) for callus induction. For shoot regeneration, calli derived from both types of explants were cultured on MS medium supplemented with various concentrations and combinations of 2,4-D, BAP, NAA, IAA $\left(0.1,0.2,0.6 \mathrm{mg} \mathrm{L}^{-1}\right)$, IBA $\left(0.5 \mathrm{mg} \mathrm{L}^{-1}\right)$ and $\mathrm{GA}_{3}$ $\left(0.1\right.$ and $\left.0.2 \mathrm{mg} \mathrm{L}^{-1}\right)$. The $\mathrm{pH}$ of the medium was adjusted to $5.8 \pm 0.1$ before addition of $0.8 \%(\mathrm{w} / \mathrm{v})$ agar for solidification. All the cultures were maintained in $16 \mathrm{~h}$ photoperiod, with light intensity of $2000-3000$ lux at $25 \pm 1^{\circ} \mathrm{C}$. Subcultures were carried out at regular intervals.

Data on percentage of callus induction, days to callus initiation, percentage of shoot regeneration, days to shoot initiation, length of shoot, number of roots plantlet ${ }^{-1}$, days to 
root initiation and length of roots were recorded. The experiments were arranged in Completely Randomized Design (CRD) with 4 replications. Data recorded for different parameters under study were statistically analyzed. The difference between the pair of means was evaluated at $5 \%$ level of significance by Duncan's Multiple Range Test (Gomez and Gomez, 1984).

\section{RESULTS AND DISCUSSION}

\section{Effect of 2,4-D and BAP on callus induction}

Result revealed that leaf segments cultured on medium supplemented with $1.0 \mathrm{mg} \mathrm{L}^{-1}$ 2,4-D combined with $1.0 \mathrm{mg} \mathrm{L}^{-1}$ BAP had produced friable and greenish calli (Fig. 1a). The highest callus frequency $(78.75 \%)$ was found in $1.0 \mathrm{mg} \mathrm{L}^{-1} 2,4-\mathrm{D}$ combined with 1.0 $\mathrm{mg} \mathrm{L}^{-1} \mathrm{BAP}$ and was induced within the minimum number (10.75) of days (Table 1 ). The lowest $(15.0 \%)$ percentage of callus was recorded in leaf segments cultured on medium with $0.20 \mathrm{mg} \mathrm{L}^{-1} \mathrm{BAP}$ without 2,4-D. It can be noted that the frequency of callus increased when BAP and 2,4-D were used together (78.75\%) instead of single use of either of them (2,4-D, 58.75\% and BAP, 38.00\%). In root tip explants, $1.0 \mathrm{mg} \mathrm{L}^{-1}$ 2,4-D combined with $0.50 \mathrm{mg} \mathrm{L}^{-1} \mathrm{BAP}$ induced the highest frequency of callus $(72.50 \%)$ within 34.00 days and the lowest callus frequency $(2.50 \%)$ was found in medium with $0.25 \mathrm{mg} \mathrm{L}^{-1} 2,4-\mathrm{D}$ and $0.50 \mathrm{mg} \mathrm{L}^{-1} \mathrm{BAP}$ and it required relatively longer duration (40.25 days). Result also revealed that some combinations failed to produce any callus (Table 1). Both auxin and cytokinin applied separately were found to induce callus from the leaf of bitter gourd. However, a combined application of auxin and cytokinin was more efficient. Similar findings were reported earlier. Many workers agreed with this agreement in different crops. Josekutty et al. (1993) observed callus from leaf explants of Coccinia indica on MS medium supplemented with $1.5 \mathrm{mg} \mathrm{L}^{-1} \mathrm{BA}, 0.5 \mathrm{mg} \mathrm{L}^{-1} \mathrm{Kn}$ and $0.5 \mathrm{mg} \mathrm{L}^{-1}$ NAA. Kumar et al. (2003) found optimal embryogenic calli/embryos of Cucumis sativus $\mathrm{L}$ induced on $\mathrm{B}_{5}$ medium supplemented with $2.0 \mathrm{mg} \mathrm{L}^{-1} 2,4-\mathrm{D}$ and $1.0 \mathrm{mg} \mathrm{L}^{-1} \mathrm{BAP}$.

\section{Effect of BAP and NAA on callus induction of bitter gourd from different explants}

Leaf segments cultured on medium supplemented with $2.0 \mathrm{mg} \mathrm{L}^{-1}$ BAP combined with $0.30 \mathrm{mg} \mathrm{L}^{-1}$ NAA produced the highest percentage of callus $(68.75 \%)$ within the minimum number of days (9.75) (Table 2). The lowest frequency of callus (26.25\%) was produced in a combination of $2.5 \mathrm{mg} \mathrm{L}^{-1} \mathrm{BAP}$ and 0.3 or $0.6 \mathrm{mg} \mathrm{L}^{-1} \mathrm{NAA}$. Nabi et al. (2002) found that the combination of $1 \mathrm{mg} \mathrm{L}^{-1} \mathrm{BAP}$ and $0.1 \mathrm{mg} \mathrm{L}^{-1} \mathrm{NAA}$ was found suitable for callus induction from leaf explant of kakrol. Chaudhury et al. (2004) reported callus formation from leaf discs of tomato on $2.0 \mathrm{mg} \mathrm{L}^{-1} \mathrm{BAP}$ and $2.0 \mathrm{mg} \mathrm{L}^{-1} \mathrm{NAA}$. In root tips, results of the present study revealed that $2.0 \mathrm{mg} \mathrm{L}^{-1} \mathrm{BAP}$ combined with $0.3 \mathrm{mg} \mathrm{L}^{-1} \mathrm{NAA}$ produced the highest callus $(80.0 \%)$ which is statistically similar with $2.0 \mathrm{mg} \mathrm{L}^{-1}$ BAP combined with $0.10 \mathrm{mg} \mathrm{L}^{-1}$ (77.5) (Table 2). The lowest percentage of callus $(27.50 \%)$ was produced in $3.0 \mathrm{mg} \mathrm{L}^{-1} \mathrm{BAP}$ with $0.3 \mathrm{mg} \mathrm{L}^{-1} \mathrm{NAA}$ and maximum number of days (33.25) was required for callus induction. Most of the calli produced from leaf segments were creamy and yellowish in colour (Fig. 1). 

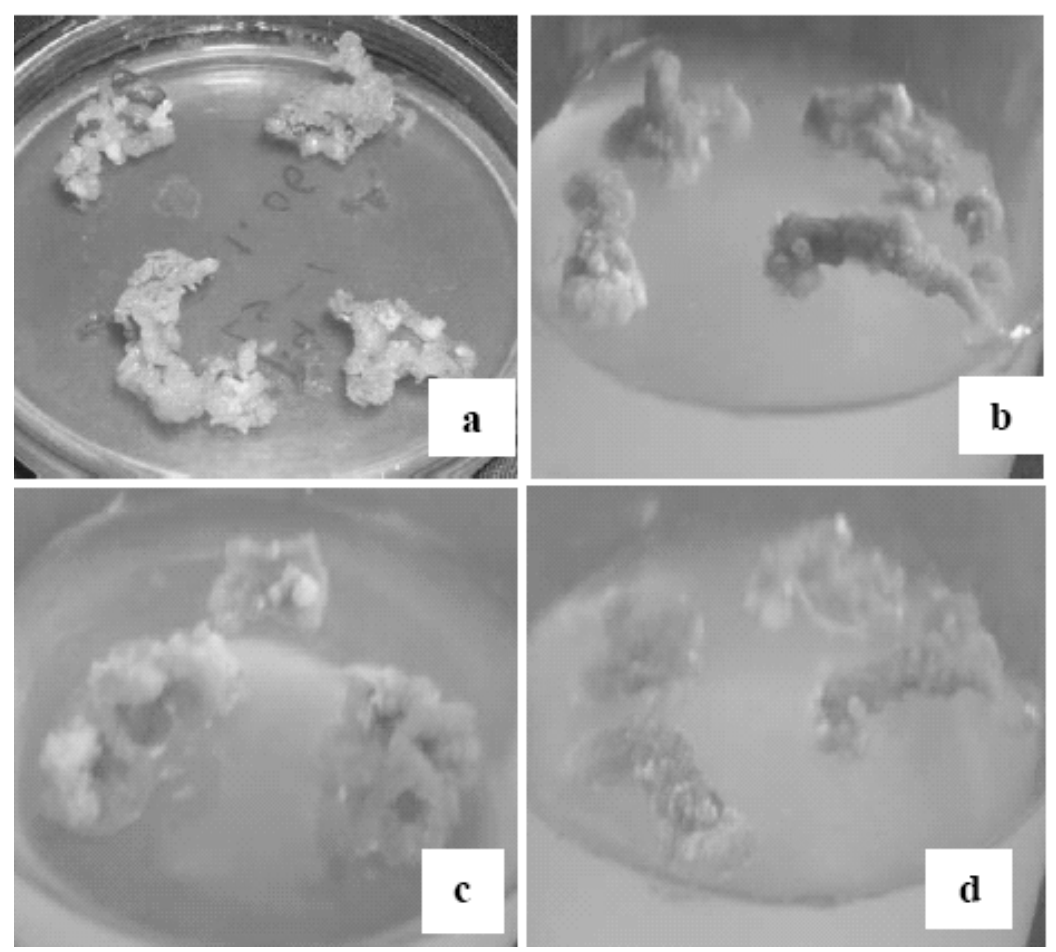

Fig. 1. Callus induced from different explants of bitter gourd cultured on media containing different concentrations of growth regulators : a) Leaf segments at $1.0 \mathrm{mg} \mathrm{L}^{-1} 2,4-\mathrm{D}$ and 1.0 $\mathrm{mg} \mathrm{L}^{-1}$ BAP (18 DAC), b) Root tips at $1.0 \mathrm{mg} \mathrm{L}^{-1}$ 2,4-D and $1.0 \mathrm{mg} \mathrm{L}^{-1}$ BAP (50 DAC), c) Leaf segments at $2.0 \mathrm{mg} \mathrm{L}^{-1} \mathrm{BAP}$ and $0.3 \mathrm{mg} \mathrm{L}^{-1} \mathrm{NAA}(16 \mathrm{DAC})$, d) Root tips at $2.0 \mathrm{mg} \mathrm{L}^{-1}$ BAP and $0.3 \mathrm{mg} \mathrm{L}^{-1} \mathrm{NAA}(32 \mathrm{DAC})$

\section{Effect of different concentrations of growth regulators on shoot regeneration}

In Leaf segments, the highest percentage (65.0\%) of shoots formation was found in $2.5 \mathrm{mg}$ $\mathrm{L}^{-1} \mathrm{BAP}$ and $0.2 \mathrm{mg} \mathrm{L}^{-1}$ IAA and the lowest percentage (55.0\%) was found in $2.0 \mathrm{mg} \mathrm{L}^{-1}$ BAP, $0.5 \mathrm{mg} \mathrm{L}^{-1} \mathrm{IBA}$ and $0.2 \mathrm{mg} \mathrm{L}^{-1} \mathrm{GA}_{3}$ (Table 3). Costa et al. (2000) found higher shoot regeneration from cotyledon of tomato in $2.5 \mathrm{mg} \mathrm{L}^{-1}$ BAP combined with $0.2 \mathrm{mg} \mathrm{L}^{-1}$ IAA. Chen et al. (2000) also observed that shoot induction rate was highest on medium supplemented with $2.0 \mathrm{mg} \mathrm{L}^{-1} \mathrm{BA}$ and IAA $0.02 \mathrm{mg} \mathrm{L}^{-1}$. The highest length of shoot $(3.95 \mathrm{~cm})$ was recorded in $2.0 \mathrm{mg} \mathrm{L}^{-1} \mathrm{BAP}, 0.5 \mathrm{mg} \mathrm{L}^{-1} \mathrm{IBA}$ and $0.2 \mathrm{mg} \mathrm{L}^{-1} \mathrm{GA}_{3}$ and lowest shoot length $(3.23 \mathrm{~cm})$ was found in $2.0 \mathrm{mg} \mathrm{L}^{-1} \mathrm{BAP}$ and $0.2 \mathrm{mg} \mathrm{L}^{-1} \mathrm{IAA}$ (Table 3 ).

The highest percentage $(65.0 \%)$ of regenerated shoots was found in $2.0 \mathrm{mg} \mathrm{L}^{-1} \mathrm{BAP}$ and $0.2 \mathrm{mg} \mathrm{L}^{-1} \mathrm{IAA}$ and the lowest (40.0\%) was obtained in $1.0 \mathrm{mg} \mathrm{L}^{-1} \mathrm{BAP}, 0.5 \mathrm{mg} \mathrm{L}^{-1} \mathrm{IBA}$ and $0.2 \mathrm{mg} \mathrm{L}^{-1} \mathrm{GA}_{3}$ in root tips (Table 3). This result agreed with Shafiullah et al. (2003). They also observed highest number of shoots in $2.5 \mathrm{mg} \mathrm{L}^{-1}$ in combination with $0.2 \mathrm{mg} \mathrm{L}^{-1}$ IAA. The highest length of shoot $(3.80 \mathrm{~cm})$ was recorded in $2.0 \mathrm{mg} \mathrm{L}^{-1} \mathrm{BAP}, 0.5 \mathrm{mg} \mathrm{L}^{-1} \mathrm{IBA}$ and $\left.\mathrm{mg} \mathrm{L}^{-1} 0.2 \mathrm{GA}_{3}\right)$ where the lowest $(3.25 \mathrm{~cm})$ was found in $2.5 \mathrm{mg} \mathrm{L}^{-1} \mathrm{BAP}$ and $0.2 \mathrm{mg} \mathrm{L}^{-1}$ 
IAA. Different combinations of BAP, 2,4-D and NAA (Stated in materials methods) used in this experiment was unable to produce any plant. Shoots formed from root tips were healthier than those from root segments (Figs. 2a \& b).

Table 1. Effect of different combinations of 2,4-D and BAP on callus induction from leaf and root explants

\begin{tabular}{l|c|c|c|c|c}
\hline \multicolumn{2}{c}{ Concentrations $\left(\mathrm{mg} \mathrm{L}^{-1}\right)$} & \multicolumn{2}{c|}{ Leaf segments } & \multicolumn{2}{c}{ Root tips } \\
\hline $2,4-\mathrm{D}$ & BAP & $\begin{array}{c}\text { \% callus } \\
\text { induction }\end{array}$ & $\begin{array}{c}\text { Days to callus } \\
\text { induction }\end{array}$ & $\begin{array}{c}\text { \% callus } \\
\text { induction }\end{array}$ & $\begin{array}{c}\text { Days to callus } \\
\text { induction }\end{array}$ \\
\hline 0 & 0.2 & $0.00 \mathrm{k}$ & $0.00 \mathrm{~h}$ & $0.00 \mathrm{k}$ & $0.00 \mathrm{~d}$ \\
& 0.5 & $0.00 \mathrm{k}$ & $0.00 \mathrm{~h}$ & $0.00 \mathrm{k}$ & $0.00 \mathrm{~d}$ \\
& 1.0 & $15.00 \mathrm{j}$ & $14.50 \mathrm{~b}$ & $0.00 \mathrm{k}$ & $0.00 \mathrm{~d}$ \\
\hline 0.25 & 2.0 & $18.75 \mathrm{i}$ & $13.50 \mathrm{~cd}$ & $0.00 \mathrm{k}$ & $0.00 \mathrm{~d}$ \\
\hline 0.50 & 0.2 & $21.25 \mathrm{hi}$ & $12.75 \mathrm{ef}$ & $0.00 \mathrm{k}$ & $0.00 \mathrm{~d}$ \\
& 0.5 & $42.50 \mathrm{de}$ & $13.50 \mathrm{~cd}$ & $2.50 \mathrm{j}$ & $40.25 \mathrm{ab}$ \\
& 1.0 & $43.75 \mathrm{~d}$ & $12.50 \mathrm{f}$ & $13.75 \mathrm{i}$ & $40.25 \mathrm{ab}$ \\
& 2.0 & $31.25 \mathrm{~g}$ & $12.75 \mathrm{ef}$ & $12.50 \mathrm{i}$ & $41.00 \mathrm{a}$ \\
\hline 1.0 & 0.2 & $23.75 \mathrm{~h}$ & $14.00 \mathrm{bc}$ & $31.25 \mathrm{~h}$ & $39.75 \mathrm{abc}$ \\
& 0.5 & $38.75 \mathrm{f}$ & $12.25 \mathrm{f}$ & $43.75 \mathrm{ef}$ & $37.50 \mathrm{abc}$ \\
& 1.0 & $37.50 \mathrm{f}$ & $12.25 \mathrm{f}$ & $46.25 \mathrm{de}$ & $36.50 \mathrm{abc}$ \\
& 2.0 & $42.50 \mathrm{de}$ & $13.50 \mathrm{~cd}$ & $41.25 \mathrm{fg}$ & $34.75 \mathrm{abc}$ \\
\hline 5.0 & 0.2 & $48.75 \mathrm{c}$ & $13.75 \mathrm{~cd}$ & $48.75 \mathrm{~d}$ & $36.75 \mathrm{abc}$ \\
& 0.5 & $67.50 \mathrm{~b}$ & $12.25 \mathrm{f}$ & $72.50 \mathrm{a}$ & $34.00 \mathrm{abc}$ \\
& 1.0 & $78.75 \mathrm{a}$ & $10.75 \mathrm{~g}$ & $62.50 \mathrm{~b}$ & $33.50 \mathrm{abc}$ \\
& 2.0 & $40.00 \mathrm{ef}$ & $13.25 \mathrm{de}$ & $52.50 \mathrm{c}$ & $32.25 \mathrm{c}$ \\
\hline & 0.2 & $0.00 \mathrm{k}$ & $0.00 \mathrm{~h}$ & $63.75 \mathrm{~b}$ & $38.00 \mathrm{abc}$ \\
& 0.5 & $0.00 \mathrm{k}$ & $0.00 \mathrm{~h}$ & $61.25 \mathrm{~b}$ & $35.00 \mathrm{abc}$ \\
& $15.00 \mathrm{j}$ & $15.50 \mathrm{a}$ & $46.25 \mathrm{de}$ & $37.50 \mathrm{abc}$ \\
& $0.00 \mathrm{k}$ & $0.00 \mathrm{~h}$ & $38.75 \mathrm{~g}$ & $32.50 \mathrm{bc}$ \\
\hline
\end{tabular}

In a column, the figures with the same letter (s) do not differ significantly; Twenty explants were cultured per treatment

\section{Effect of different concentrations of growth regulators on rooting of shoot}

The highest percentage $(65.0 \%)$ of roots initiation was found in $2.5 \mathrm{mg} \mathrm{L}^{-1} \mathrm{BAP}$ and 0.60 $\mathrm{mg} \mathrm{L}^{-1} \mathrm{NAA}$ and the lowest percentage (37.5) was found in $2.0 \mathrm{mg} \mathrm{L}^{-1} \mathrm{BAP}$ and $0.2 \mathrm{mg} \mathrm{L}^{-1}$ IAA in leaf segments. The highest number of root (6.75) and length of root was found in $3.0 \mathrm{mg} \mathrm{L}^{-1} \mathrm{BAP}$ and $0.1 \mathrm{mg} \mathrm{L}^{-1} \mathrm{NAA}$ and lowest number (4.25) and length was found in $2.0 \mathrm{mg} \mathrm{L}^{-1}$ BAP and $0.2 \mathrm{mg} \mathrm{L}^{-1}$ IAA (Table 4). Agarwal and Kamal (2004) observed root differentiation of $M$. charantia on MS medium containing BAP and NAA. Ren et al. (2000) 
also reported rooting of water melon to be achieved easily in half-strength MS medium and $0.1 \mathrm{mg}$ kinetin or $0.1 \mathrm{mg}$ NAA or $0.1 \mathrm{mg} \mathrm{L}^{-1}$ IAA.

Table 2. Effect of different combinations of BAP and NAA for callus induction from leaf segments

\begin{tabular}{c|c|c|c|c|c}
\hline \multicolumn{2}{c|}{ Concentrations $\left(\mathrm{mg} \mathrm{L}^{-1}\right)$} & \multicolumn{2}{c|}{ Leaf segments } & \multicolumn{2}{c}{ Root tips } \\
\hline BAP & NAA & $\begin{array}{c}\text { \% callus } \\
\text { induction }\end{array}$ & $\begin{array}{c}\text { Days to callus } \\
\text { induction }\end{array}$ & $\begin{array}{c}\text { \% callus } \\
\text { induction }\end{array}$ & $\begin{array}{c}\text { Days to callus } \\
\text { induction }\end{array}$ \\
\hline \multirow{2}{*}{1.5} & 0.1 & $52.50 \mathrm{c}$ & $14.25 \mathrm{a}$ & $0.00 \mathrm{f}$ & $0.00 \mathrm{f}$ \\
& 0.3 & $36.25 \mathrm{~d}$ & $12.50 \mathrm{c}$ & $0.00 \mathrm{f}$ & $0.00 \mathrm{f}$ \\
\hline 2.0 & 0.6 & $28.75 \mathrm{e}$ & $12.25 \mathrm{c}$ & $0.00 \mathrm{f}$ & $0.00 \mathrm{f}$ \\
\hline \multirow{2}{*}{2.5} & 0.1 & $60.00 \mathrm{~b}$ & $10.25 \mathrm{e}$ & $77.50 \mathrm{a}$ & $25.50 \mathrm{e}$ \\
& 0.3 & $68.75 \mathrm{a}$ & $9.75 \mathrm{e}$ & $80.00 \mathrm{a}$ & $24.50 \mathrm{e}$ \\
& 0.6 & $40.00 \mathrm{~d}$ & $12.25 \mathrm{c}$ & $67.50 \mathrm{bc}$ & $27.00 \mathrm{~d}$ \\
\hline 3.0 & 0.1 & $38.75 \mathrm{~d}$ & $11.25 \mathrm{~d}$ & $72.50 \mathrm{~b}$ & $27.25 \mathrm{~d}$ \\
& 0.3 & $26.25 \mathrm{e}$ & $12.25 \mathrm{c}$ & $68.75 \mathrm{bc}$ & $27.50 \mathrm{~d}$ \\
& 0.6 & $26.25 \mathrm{e}$ & $13.50 \mathrm{~b}$ & $66.25 \mathrm{c}$ & $29.00 \mathrm{c}$ \\
\hline
\end{tabular}

In a column, the figures with the same letter(s) do not differ significantly, Twenty explants were cultured per treatment

Table 3. Effect of different concentrations and combinations of growth regulators for different parameters of shoot

\begin{tabular}{|c|c|c|c|c|c|c|}
\hline \multicolumn{3}{|c|}{ Growth regulators $\left(\mathrm{mg} \mathrm{L}^{-1}\right)$} & \multicolumn{2}{|c|}{ Leaf segments } & \multicolumn{2}{|c|}{ Root tips } \\
\hline $\begin{array}{c}\text { Cytokinins } \\
(\mathrm{BAP})\end{array}$ & & & $\begin{array}{c}\text { Percentage of } \\
\text { shoots }\end{array}$ & Shoot length & $\begin{array}{c}\text { Percentage of } \\
\text { shoots }\end{array}$ & Shoot length \\
\hline \multicolumn{7}{|c|}{ IAA } \\
\hline \multirow{2}{*}{2.0} & \multicolumn{2}{|c|}{0.2} & $58.0 \mathrm{c}$ & 3.23 & $65.0 \mathrm{a}$ & 3.3 \\
\hline & \multicolumn{2}{|c|}{0.6} & $0.00 \mathrm{e}$ & 0.00 & $0.00 \mathrm{e}$ & 0.0 \\
\hline \multirow{3}{*}{2.5} & \multicolumn{2}{|c|}{0.2} & $65.0 \mathrm{a}$ & 3.25 & $45.0 \mathrm{c}$ & 3.25 \\
\hline & \multicolumn{2}{|c|}{0.6} & $0.00 \mathrm{e}$ & 0.00 & $55.0 \mathrm{~b}$ & 0.0 \\
\hline & IBA & $\mathrm{GA}_{3}$ & & & & \\
\hline 1.0 & 0.5 & 0.2 & $60.0 \mathrm{~b}$ & 3.40 & $0.00 \mathrm{e}$ & 0.0 \\
\hline 2.0 & 0.5 & 0.2 & $55.0 \mathrm{~d}$ & 3.95 & $40.0 \mathrm{~d}$ & 3.4 \\
\hline 2.5 & 0.5 & 0.2 & $0.00 \mathrm{e}$ & 0.00 & $55.0 \mathrm{~b}$ & 3.8 \\
\hline
\end{tabular}

In a column, the figures with the same letter(s) do not differ significantly 
In root tips, the highest percentage $(70.0 \%)$ of root was found in $2.5 \mathrm{mg} \mathrm{L}^{-1} \mathrm{BAP}$ and 0.5 $\mathrm{mg} \mathrm{L}^{-1}$ IBA and the lowest percentage (37.5\%) was found in $2.0 \mathrm{mg} \mathrm{L}^{-1} \mathrm{BAP}$ and $0.2 \mathrm{mg} \mathrm{L}^{-1}$ IAA (Table 4). The highest number of roots (7.0) was found in $2.0 \mathrm{mg} \mathrm{L}^{-1} \mathrm{BAP}$ and $0.5 \mathrm{mg}$ $\mathrm{L}^{-1}$ IBA and the lowest (4.25) was found in $2.0 \mathrm{mg} \mathrm{L}^{-1} \mathrm{BAP}$ and $0.2 \mathrm{mg} \mathrm{L}^{-1}$ IAA and $2.5 \mathrm{mg}$ $\mathrm{L}^{-1} \mathrm{BAP}$ and $0.2 \mathrm{mg} \mathrm{L}^{-1}$ IAA. The highest root length $(2.25 \mathrm{~cm})$ was found in $2.0 \mathrm{mg} \mathrm{L}^{-1}$ BAP and $0.3 \mathrm{mg} \mathrm{L}^{-1} \mathrm{NAA}$ and $2.5 \mathrm{mg} \mathrm{L}^{-1} \mathrm{BAP}$ and $0.6 \mathrm{mg} \mathrm{L}^{-1} \mathrm{NAA}$ and lowest was found in $2.0 \mathrm{mg} \mathrm{L}^{-1} \mathrm{BAP}$ and $0.2 \mathrm{mg} \mathrm{L}^{-1}$ IAA (Table 4). Fig. 2c shows a rooted plantlet of bitter gourd regenerated from root tip callus.

Table 4. Effect of different concentrations and combinations of growth regulators for different parameters of root

\begin{tabular}{|c|c|c|c|c|c|c|c|}
\hline \multicolumn{2}{|c|}{$\begin{array}{l}\text { Growth regulators } \\
\qquad\left(\mathrm{mg} \mathrm{L}^{-1}\right)\end{array}$} & \multicolumn{3}{|c|}{ Leaf segments } & \multicolumn{3}{|c|}{ Root tips } \\
\hline $\begin{array}{l}\text { Cytokinins } \\
\text { (BAP) }\end{array}$ & Auxins & $\begin{array}{l}\text { Percentage } \\
\text { of roots * }\end{array}$ & $\begin{array}{c}\text { Number of } \\
\text { root }\end{array}$ & $\begin{array}{c}\text { Root length } \\
(\mathrm{cm})\end{array}$ & $\begin{array}{l}\text { Percentage } \\
\text { of roots * }\end{array}$ & $\begin{array}{c}\text { Number of } \\
\text { roots }\end{array}$ & $\begin{array}{l}\text { Root length } \\
\quad(\mathrm{cm})\end{array}$ \\
\hline \multicolumn{8}{|c|}{ 2,4-D } \\
\hline 1.0 & 1.0 & $60.0 \mathrm{~b}$ & 5.50de & 2.18 & $0.00 \mathrm{~g}$ & $0.00 \mathrm{e}$ & 0.00 \\
\hline 1.5 & 1.0 & $52.5 \mathrm{~cd}$ & $5.25 \mathrm{e}$ & 2.15 & $0.00 \mathrm{~g}$ & $0.00 \mathrm{e}$ & 0.00 \\
\hline \multirow[t]{2}{*}{2.0} & 1.0 & $0.00 \mathrm{~g}$ & $0.00 \mathrm{~g}$ & 0.00 & $0.00 \mathrm{~g}$ & $0.00 \mathrm{e}$ & 0.00 \\
\hline & IBA & & & & & & \\
\hline 1.0 & 0.5 & $52.5 \mathrm{~cd}$ & $6.25 b c$ & 2.13 & $0.00 \mathrm{~g}$ & $0.00 \mathrm{e}$ & $0.00 \mathrm{~g}$ \\
\hline 2.0 & 0.5 & $60.0 \mathrm{~b}$ & $6.50 \mathrm{ab}$ & 2.16 & $62.5 b$ & $6.25 b$ & 2.13 \\
\hline \multirow[t]{2}{*}{2.5} & 0.5 & $0.00 \mathrm{~g}$ & $0.00 \mathrm{~g}$ & 0.00 & $70.0 \mathrm{a}$ & 7.0a & 2.16 \\
\hline & IAA & & & & & & \\
\hline \multirow[t]{2}{*}{2.0} & 0.2 & $37.5 \mathrm{f}$ & $4.25 f$ & 2.00 & $37.5 \mathrm{f}$ & $4.25 \mathrm{~d}$ & 2.10 \\
\hline & 0.6 & $0.00 \mathrm{~g}$ & $0.00 \mathrm{~g}$ & 0.00 & $0.00 \mathrm{~g}$ & $0.00 \mathrm{e}$ & 0.00 \\
\hline \multirow[t]{2}{*}{2.5} & 0.2 & $42.5 \mathrm{e}$ & $4.25 \mathrm{f}$ & 2.23 & $42.5 e$ & $4.25 \mathrm{~d}$ & 2.13 \\
\hline & 0.6 & $0.00 \mathrm{~g}$ & $0.00 \mathrm{~g}$ & 0.00 & $0.00 \mathrm{~g}$ & $0.00 \mathrm{e}$ & 0.00 \\
\hline \multirow[t]{3}{*}{3.0} & 0.2 & $0.00 \mathrm{~g}$ & $0.00 \mathrm{~g}$ & 0.00 & $0.00 \mathrm{~g}$ & $0.00 \mathrm{e}$ & 0.00 \\
\hline & 0.6 & $0.00 \mathrm{~g}$ & $0.00 \mathrm{~g}$ & 0.00 & $0.00 \mathrm{~g}$ & $0.00 \mathrm{e}$ & 0.00 \\
\hline & NAA & & & & & & \\
\hline \multirow[t]{2}{*}{2.0} & 0.6 & $0.00 \mathrm{~g}$ & $0.00 \mathrm{~g}$ & 0.00 & $50.0 \mathrm{~d}$ & $5.38 \mathrm{c}$ & 2.13 \\
\hline & 0.3 & $62.5 \mathrm{ab}$ & $6.30 \mathrm{abc}$ & 2.25 & $65.0 \mathrm{~b}$ & $6.30 \mathrm{~b}$ & 2.25 \\
\hline \multirow[t]{2}{*}{2.5} & 0.1 & $55.0 \mathrm{c}$ & $6.25 b c$ & 2.35 & $0.00 \mathrm{~g}$ & $0.00 \mathrm{e}$ & 0.00 \\
\hline & 0.6 & $65.0 \mathrm{a}$ & $5.95 \mathrm{~cd}$ & 2.15 & $55.0 \mathrm{c}$ & $4.95 \mathrm{c}$ & 2.25 \\
\hline \multirow[t]{2}{*}{3.0} & 0.1 & $50.0 d$ & $6.75 a$ & 2.45 & $40.0 \mathrm{e}$ & $4.75 \mathrm{c}$ & 2.15 \\
\hline & 0.3 & $42.5 \mathrm{e}$ & $5.25 \mathrm{e}$ & 2.22 & $0.00 \mathrm{~g}$ & $0.00 \mathrm{e}$ & 0.00 \\
\hline
\end{tabular}

In a column, the figures with the same letter(s) do not differ significantly, ${ }^{*}$ Roots formed either regenerated shoot or callus 


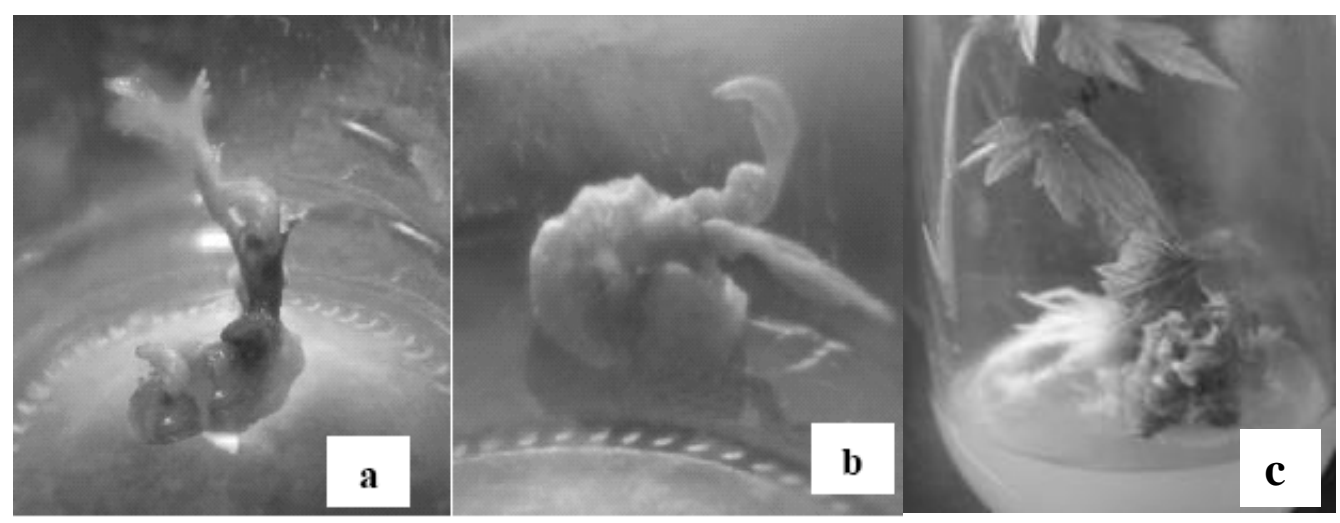

Fig. 2. a) Shoot regeneration from root tip callus of bitter gourd cultured on media containing 2.0 $\mathrm{mg} \mathrm{L}^{-1}$ 2,4-D, $0.50 \mathrm{mg} \mathrm{L}^{-1}$ IBA and $0.20 \mathrm{mg} \mathrm{L}^{-1} \mathrm{GA}_{3}$; b) Leaf segments callus cultured on media containing at $2.5 \mathrm{mg} \mathrm{L}^{-1} \mathrm{BAP}$ and $0.20 \mathrm{IAA} \mathrm{mg} \mathrm{L}^{-1}$ (35 DAC); c) Rooted plantlets from root tip callus cultured on media containing $2.0 \mathrm{mg} \mathrm{L}^{-1} \mathrm{BAP}, 0.50 \mathrm{mg} \mathrm{L}^{-1} \mathrm{IBA}$ and 0.20 $\mathrm{mg} \mathrm{L}^{-1} \mathrm{GA}_{3}(80 \mathrm{DAC})$

\section{Establishment of plants}

After sufficient development of shoot and root systems, the small plantlets were taken out from the culture vessels with proper care without damaging the roots. The plantlets were then transplanted in small pots. When the plantlet grew to a height of 5-6 cm, they were transferred to plastic pots. The growth condition of plantlets was satisfactory and the survivability of plant more than $75 \%$. The pots with the established plants were then kept in natural condition, allowed them to grow with proper care.

\section{ACKNOWLEDGEMENT}

The research grant from Bangladesh Council of Scientific and Industrial Research (BCSIR), Dhaka. is gratefully acknowledged.

\section{REFERENCES}

Chaudhury, Z., Habib, D., Rashid, H. and Qureshi, A. S. 2004. Regeneration from various explants of in vitro seedling of tomato. Pakistan J. Biol. Sci., 7(2) : 269-272.

Chen, H., Zhang, J., Zhong, J. and Yu, J. 2000. Plant regeneration from hypocotyl explants cultured in vitro and histological observations in Lycoperiscon esculentum Mill. Xibei Zhiwu Xuebao, 20(5) : 759-765.

Choudhury, B. 1967. Vegetables National Book Trust. New Delhi, India.

Costa, G. M., Noqueira, F. T. S., Otoni, W. C. and Brommonschenkel, S. H. 2000. In vitro regeneration of processing tomato (Lycopersicon esculentum Mill.) IPA-5 and IPA-6. Cienciae-Agrotecnologia, 24(3) : 671-678.

Gomez, A. C. and Gomez, A. A. 1984. Statistical Procedures for Agricultural Research (2nd edn.). John Wiley and Sons, New York. pp. 207-215. 
Jiratchariyakul, W., Wiwat, C., Vongsakul, M., Somanabandhu, A., Leelamanit, W., Fujii, I., Suwannaroj, N., Ebizuka, Y., Weena, J., Chanpen, W., Molvibha, V., Somanabandhu, A., Leelamanit, W. and Suwannarol, N. 2001. HIV inhibitor from Thai bitter gourd. Planta Medica., 67(4) : 350-353.

Josekutty, P. C., Shah, S., Prathapasenan, G. and Shah, S. 1993. Direct and indirect organogenesis in Coccinia indica. J. Hort. Sci., 68(1) : 31-35.

Khan, R. A. 1999. A study of Karela (Momordica charantia Linn.) on blood glucose. Hamdard Medicus., 42(2) : 56-61.

Kirtikar, K. R. and Basu, B. D. 1994. Momordica charantia Linn. In: Indian Medicinal Plants. (Eds. Singh B and Signh MP), Vol.II Dehra Dun. India. pp. 1130-1132.

Kumar, H. G. A., Murthy, H. N. and Paek, K. Y. 2003. Embryogenesis and plant regeneration from anther cultures of Cucumis sativus L. Scientia Hortic., 98(3) : 213-222.

Lim, T. K. 1998. Loofahs gourds, melons and snake beans. The New Rural Industries. (ed. : K W Hyde.) Canberra, Rural Industries Res. and Dev. Corp, pp. 212-218.

Murashige, T. and Skoog, T. 1962. A revised medium for rapid growth and bioassays with tobacco tissue cultures. Physiol. Plant., 15 : 473-497.

Naseem, M. Z., Patil, S. R., Patil, S. R., Ravindra, R. and Patil, S. B. 1998. Antispennatogenic and androgenic activities of Momordica charantia (Karela) in albino rats. J. Ethnopharmacol. 61 (1) : 9-16.

Perl, M. 1988. The biochemical basis of the hypoglycemic effect of some plant extract. In : Craker L. E. and Simon J. E. (eds.), Herbs, Species and Medicinal plants : Recent advantaces in botany, horticulture and pharmacology. Orys Press, Phoenix AZ., 3 : 49-70.

Ren, C., Dong, Y., Hong, Y. Zhao, Y., Ren, C., Dong, Y. Y., Hong, Y. H. and Zhao, Y. 2000. Tissue culture of watermelon. J. Hunan Agril. Univ., 26(1) : 50-53.

Reyes, M. E. C., Gildemacher, B. H. and Jansen, G. J. 1994. Momordica L. In: Plant Resources of South-East Asia : Vegetables. (ed. Siemonsma, J. S. and K. Piluek). Pudoc. Sci. Pub., pp. 206-210.

Shafiullah, M., Sikdar, B. and Joarder, I. 2003. Embryogenesis and organogenesis from cotyledonderived callus in bitter gourd. Mol. Biol. Biotech. J., 1(1\&2) : 17-19.

Xue, Y., Song, S., Chen, H., Xue, Y., Song, S. H., Chen, H. and Peron, J. Y. 1998. Possible anti-tumor promoting properties of bitter gourd and some Chinese vegetables. Third international symposium on diversification of vegetable crops. Belling, China, 24-27 September 1996. Acta Hort., 467 : 55-64.

Yen, G. C. and Hwang, L. S. 1985. Lycopene from the seeds of ripe bitter melon (Momordica charantia) as a potential red food colorant. II. Storage stability, preparation of powdered lycopene and food application. .J Chin. Agr. Chem. Soc., 23 : 151-161. 